\title{
Log Splitter Design and Construction
}

\section{Projektiranje i konstrukcija uređaja za cijepanje drva}

\author{
Original scientific paper • Izvorni znanstveni rad \\ Received-prispjelo: 4. 9. 2013. \\ Accepted-prihvaćeno: 14. 1. 2015. \\ UDK: $630 * 823.13$ \\ doi:10.5552/drind.2015.1349
}

\begin{abstract}
Heating by solid fuels, and especially fire wood, belongs to the most asked and requested types of heating in cottages. One of the main problems of heating is wood splitting as a first operation. A very useful tool for splitting of wood material is a log splitter. This contribution is focused on how to apply a screw type log splitter in wood splitting. A set of experiments have been realized to get an appropriate shape of the splitting cone, which will provide an improved splitting action. The cone has been manufactured on the basis of the experimental results. The experimental apparatus has been developed to determine the validity of the splitting cone and its geometry design.
\end{abstract}

Keywords: log splitter, splitting cone, material selection, tool geometry, wood splitting

SAŽETAK • Grijanje na kruta goriva, posebno na drva za ogrjev, pripada među najčešće vrste grijanja u vikend kućama. Jedan od glavnih problema tog načina grijanja jest potreba cijepanja drva prije loženja. Vrlo koristan alat za cijepanje drvnog materijala jest cjepač drva. Ovaj je rad usmjeren na specifičnu upotrebu vijčanog tipa cjepača drva koji znatno olakšava cijepanje drva. Klin za cijepanje drva proizveden je na bazi eksperimentalnih rezultata istraživanja. Razvijena je eksperimentalna oprema za cijepanje drva kako bi se ispitala valjanost klina za cijepanje i njegova geometrija.

Ključne riječi: cjepač drva, klin za cijepanje, odabir materijala, geometrija alata, cijepanje drva

\section{INTRODUCTION \\ 1. UVOD}

Wood is an important natural resource, one of the few that are renewable. It is prevalent in our everyday lives and economy, in wood-frame houses and furniture; fence posts and utility poles or fire wood. The anatomical structure of wood affects strength properties, appearance, resistance to penetration by water and chemicals, resistance to decay, pulp quality, and the chemical reactivity of wood. Many mechanical properties of wood, such as bending and crushing strength and hardness, depend upon the density of wood; denser woods are generally stronger.
Wood is a complex polymeric structure consisting of lignin and carbohydrates, which form the visible lignocellulosic structure of wood. Minor amounts of other organic chemicals and minerals are also present, but not contributing to wood structure. The organic chemicals are diverse and can be removed from the wood with various solvents. The minerals constitute the ash residue remaining after ignition at a high temperature (Kretschmann, 2007).

Heating by solid fuels, and especially fire wood, belongs to the most asked and requested types of heating in cottages. With increasing costs of electric energy and gas, the traditional type of fuel comes into attention also by people living in family houses. One of the

\footnotetext{
${ }^{1}$ Authors are assistants at Technical University in Zvolen, Faculty of Environmental and Manufacturing Technology, Department of Mechanics and Mechanical Engineering, Zvolen, Slovakia.

${ }^{1}$ Autori su asistenti Tehničkog sveučilišta u Zvolenu, Fakultet za okolišne i proizvodne tehnologije, Odjel za mehaniku i strojarstvo, Zvolen, Slovačka.
} 
main problems of heating is wood splitting as a first operation.

A very useful tool for splitting of wood is a log splitter. Splitting a log is a hard work, whether you do it with an axe or with sledgehammer and wedge. The cone achieves a high degree of efficiency because of its shape and weight.

This contribution is focused on how to apply a splitting cone in log splitting. The cone has a tapered conical shape, which extends from a pointed forward end to an enlarged diameter base. A log to be split is positioned contiguous to the pointed end of the cone. As the cone rotates, its threads draw the log onto progressively larger diameter portions of the cone, causing the log to split apart. This cone provides an improved splitting action, and is relatively easy and cheap to build. Moreover, it prevents logs from becoming stuck on the base part. The disadvantage could be the safety of the operator, because with loose clothes there is a risk of getting caught in the rotating cone or the cone can be dangerous if it becomes stuck in the log. Although a good log splitter can save the operator hours of work with a maul, it is not possible to make it 100 percent safe. Many occupational diseases and injuries occur in forestry and wood processing industry (Suchomel et al., 2011), and therefore work safety is very important. A safety zone should be established around the splitter to prevent injury from flying splinters of wood.

\section{THEORETICAL BACKGROUND \\ 2. TEORIJSKE OSNOVE}

Fracture mechanics is a series of models used to describe the influence of cracks and defects on material behaviour. The work of Griffith (Griffith, 1921) proved that cracks and defects dictate the strength of material more than any other single feature. He arrived at a formula for the fracture stress:

$$
\sigma_{\text {crack }}=\sqrt{(E \cdot R / \pi \cdot a)}
$$

where $E$ is Young's modulus, $R$ the specific work of fracture and $a$ the size of the crack that extends through the thickness of the body. It can be seen that $\sigma_{\text {crack }}$ depends upon both stress and size of crack, not just stress alone. The cracking stress is high when the crack size is small and vice versa. There is a critical crack length below which the crack will not run for a given applied stress, and a critical applied stress below which a crack of given length will not run. The lowest possible value for $R$ is the thermodynamic surface free energy $Y$ that Griffith believed was correct for his experiments on glass, so he wrote $Y$ in place of $R$.

Fracture mechanics deals with the whole field of stress and strain around discontinuities to determine the critical loads for fracture. Formulae for stress intensity $K$ has the general form

$$
K=\sigma \sqrt{(\pi \cdot a) \cdot Y \cdot(a / W)}
$$

where $s$ is applied stress and $a$ is the size of the crack (in general, 'size' may be length, half-length, depth of the crack depending on circumstances; for a small crack in a large plate, a is the half-length of the crack that extends through the thickness of the body). $W$ is some characteristic dimension of the cracked body. $Y(a / W)$ is a non-dimensional 'shape factor' that depends on the geometry of the body, orientation of crack and the way in which loads are applied.

When a cracked body is loaded, a stress intensity appears around the crack tip and if the body is unloaded before cracking occurs, $K$ disappears in the same way that stress (or indeed strain) increases or decreases in a flawless body. However, experiments show that cracking takes place at a critical value of the stress intensity factor, called $K_{C}$, and this becomes another mechanical property to indicate resistance to cracking. Then, for fracture at stress $\sigma_{\text {crack}}$,

$$
K_{c}=\sigma_{\text {crack }} \sqrt{(\pi \cdot a) \cdot Y \cdot(a / W)}
$$

where $K_{C}$ has peculiar units $\mathrm{N} / \mathrm{m}^{3 / 2}$.

Comparison of Eq. (3) and the Griffith expression (1) shows that

$$
K_{c}^{2}=E \cdot R
$$

where $K_{C}$ is a combination of two parameters, i.e. Young's modulus $E$ and the specific work of fracture $R$. The attainment of a critical stress intensity factor at fracture is the same as satisfying an energy-based criterion determined from the integrated stress and strain fields around the crack and in the body generally. $Y(a / W)$ generalizes the Griffith formula to any type of cracked body.

Stress intensity factors are often written with Roman number subscripts I, II or III. The subscripts represent the mode of cracking, i.e. the way in which separation occurs at the crack tip. Mode I refers to crack opening by simple tension; mode II to in-plane shear cracking where the crack faces slide along one another; mode III also refers to shear, but to cracking by out-of-plane (twisting) sliding motion across the crack faces (Figure 1). The notation is sometimes used inconsistently, since a subscript I is often employed to indicate tensile cracking in plane strain (thick plates, where the critical stress intensity factor $K_{I C}$ is least owing to high hydrostatic stresses, thus leading to conservative design), whereas it is just as possible to have tensile cracking under plane stress (thin sheets) where toughness is greater owing to less constraint). A further confusion is that critical stress intensity factors are sometimes called the 'fracture toughness'. Fracture toughness means the specific work of cracking $R$. In
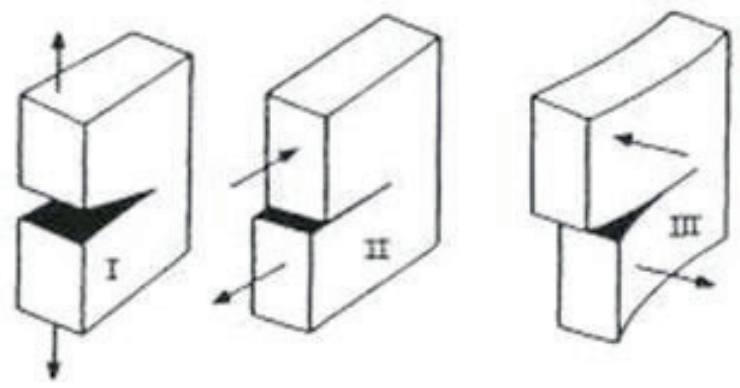

Figure 1 Types of cracks

Slika 1. Vrste pukotina 
any case, much cracking takes place in mixed mode, meaning that the crack opening has both tensile and shear components, as when the path of cracking is curved (Atkins, 2009; Smith et al., 2003).

Some investigations on the fracture behaviour of wood in relation to its microstructure were reported by Stanzl-Tschegg (2006). The fracture properties of different hard- and softwood species have been characterized by the wedge splitting technique (Tschegg, 1986) as a rather new fracture mechanical method and were correlated with the resulting fracture morphology. With this method, not only the fracture toughness $K_{\mathrm{IC}}$, but also the specific fracture energy $G_{\mathrm{f}}$ needed to completely separate a specimen, has been determined. Several parameters, which do not only determine the mechanical, but also the fracture properties, have been studied (Stanzl-Tschegg, 2006).

\section{MATERIALS AND METHODS 3. MATERIJAL I METODE}

At first, the material of the cone has to be chosen. In the previous study (Mečiarová and Minárik, 2012), some aspects in choosing the material were considered:

- conditions of dividing;

- properties and structure of divided wood and its amount (periodicity of cone using);

- machine tool construction (its stiffness);

- cone construction;

- material price.

When selecting a material, the most important factors to consider are hardness and ductility, especially in processes with a higher load. In addition, wood fibres can contain a natural acid, which can cause damage to machines.

Based on the above findings, four materials steels - have been chosen for the cone production: common carbon steel/structural steel (E335), alloy special steel $(16 \mathrm{MnCr} 5)$, martensitic stainless steel (X39Cr13) and high-speed tool steel (HS10-4-3-10). Each of these steels has certain limitations, properties, structure, price and use. The surface quality of processed wood was not important in this case.

The steels X39Cr13 and HS10-4-3-10 had a better wear resistance than the steels $\mathrm{E} 335$ and $16 \mathrm{MnCr} 5$, so they are more suitable in this case. According to different total costs of selected materials (Table 1), additional experiments for material selection were carried out. In the experiments, the tooth shape and tool material have been investigated.

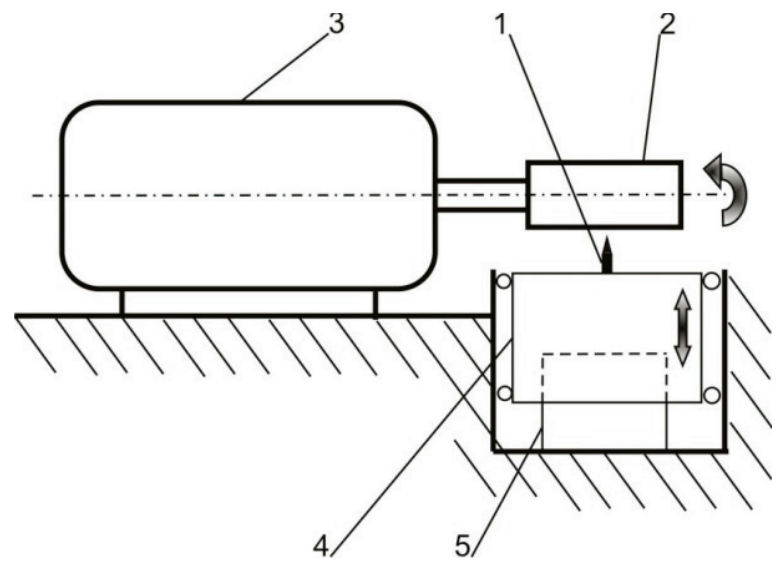

Figure 2 Scheme of mechanisms for the determination of tooth shape ( 1 - teeth; 2 - wood: oak, spruce; 3 - drive unit; 4 - fixture, 5 - linear support)

Slika 2. Shema mehanizma za određivanje oblika zuba ( 1 - zub; 2 - drvo: hrast, smreka; 3 - pogonska jedinica; 4 - učvršćenje; 5 - linearna potpora)

Selected materials and teeth specimens are shown in Table 2. The teeth specimens were pressed into the rotated wood (oak, spruce) on a machine tool (Figure 2). Cutting conditions were selected as follows: spindle speed $n=350 \mathrm{rev} / \mathrm{min}$, depth of cut $a_{p}=2 \mathrm{~mm}$; cutting time $t_{c}=1 \mathrm{~min}$. The tooth behaviour during cone rotation was simulated by real conditions in the experiment. At the tooth, it comes to wear and forces action. The forces components and their interaction were analysed in detail. The teeth on the cone were designed on the basis of this analysis and the experiment (performed by Mečiarová and Minárik, 2012) has confirmed that steels X39Cr13 and HS10-4-3-10 are the most suitable for the cone production.

Splitting is often used with wet wood cutting, therefore the suitable material for cone production is steel X39Cr13. It is a martensitic stainless steel, which resists weak acids contained in wood fibres. Another advantage of this material is the hardness and abrasion resistance resulting in preserving ductility in product core. The disadvantage (shown in Table 1) could be the higher purchase costs, but with respect to the total costs of the machined cone and its tool life, it is not a primary criterion for its selection.

Secondly, the point angle of the cone needs to be determined. In the experiment, three cone specimens made of E335 structural steel have been used. The cone specimens (Figure 3 ) with point angle of $40^{\circ}$ (cone 1), $60^{\circ}$ (cone 2), and $80^{\circ}$ (cone 3 ), were sunk into the spruce wood (Picea abies) with 18 percent humidity (Figure 4). Each cone had a $40 \mathrm{~mm}$ diameter and was

Table 1 Comparison of the total costs of selected steels

Tablica 1. Usporedba ukupnih troškova odabranih čelika

\begin{tabular}{|l|c|c|c|c|}
\hline Steel / Čelik & $\begin{array}{c}\text { E335 } \\
\text { (No. } 1.0060)\end{array}$ & $\begin{array}{c}16 \mathrm{MnCr} 5 \\
(\text { No. 1.7131) }\end{array}$ & $\begin{array}{c}\text { X39Cr13 } \\
(\text { No. 1.4031) }\end{array}$ & $\begin{array}{c}\text { HS10-4-3-10 } \\
(\text { No. 1.3207) }\end{array}$ \\
\hline $\begin{array}{l}\text { Material costs / Troškovi materijala } \\
(\varnothing 80 \times 200)\end{array}$ & $7.03 €$ & $15.54 €$ & $20.35 €$ & $27.85 €$ \\
\hline Heat treatment costs / Troškovi toplinske obrade & $0 €$ & $20.75 €$ & $20.75 €$ & $20.75 €$ \\
\hline Production costs / Troškovi proizvodnje & $26.55 €$ & $26.55 €$ & $34.50 €$ & $34.50 €$ \\
\hline Total costs / Ukupni troškovi & $33.58 €$ & $62.84 €$ & $67.65 €$ & $83.10 €$ \\
\hline
\end{tabular}


Table 2 Teeth specimens

Tablica 2. Uzorci zubi

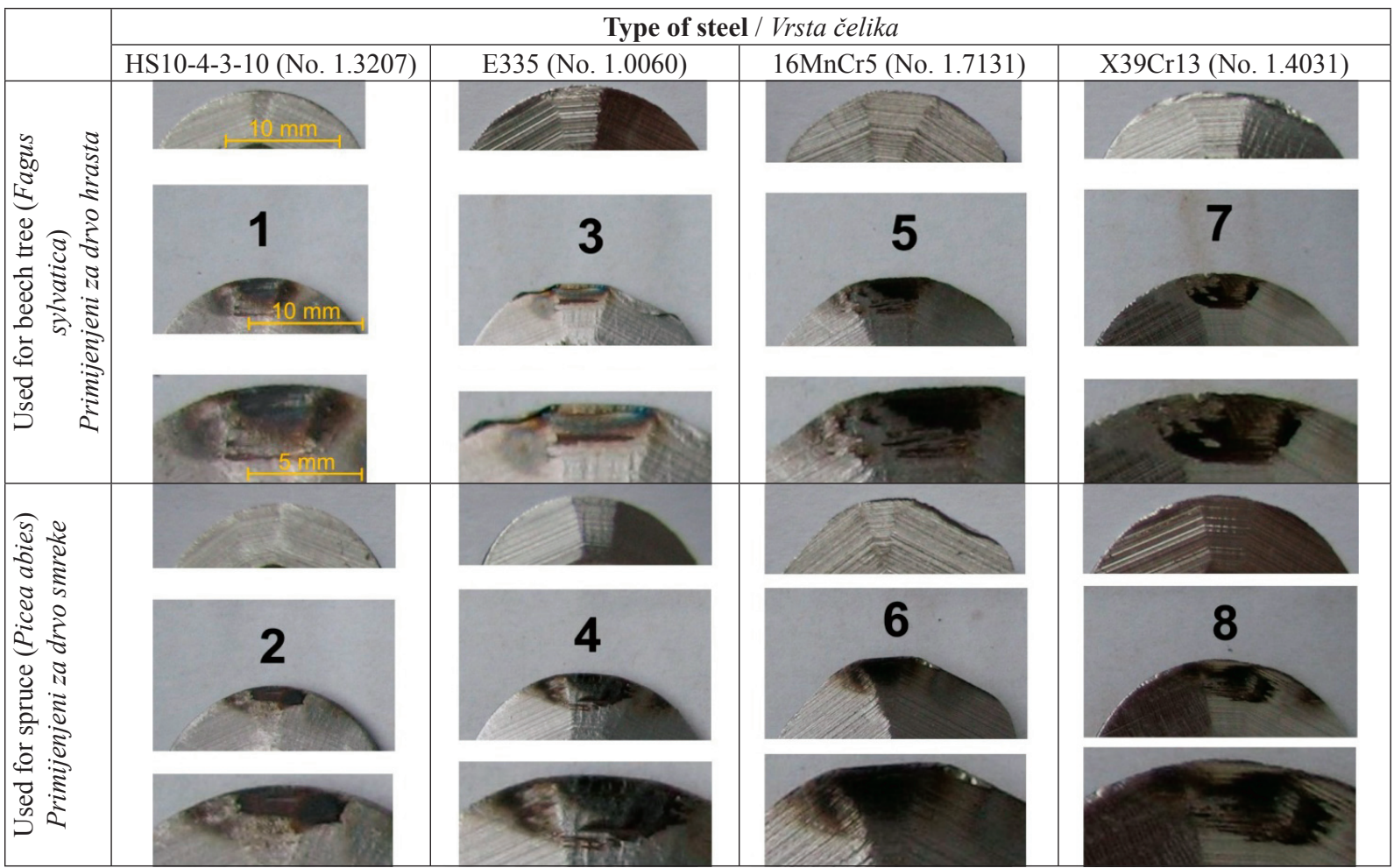

applied to 9 wood specimens, making a total of 27 measurements.

While the cone specimens were sunk, the splitting force process was monitored. The results were recorded

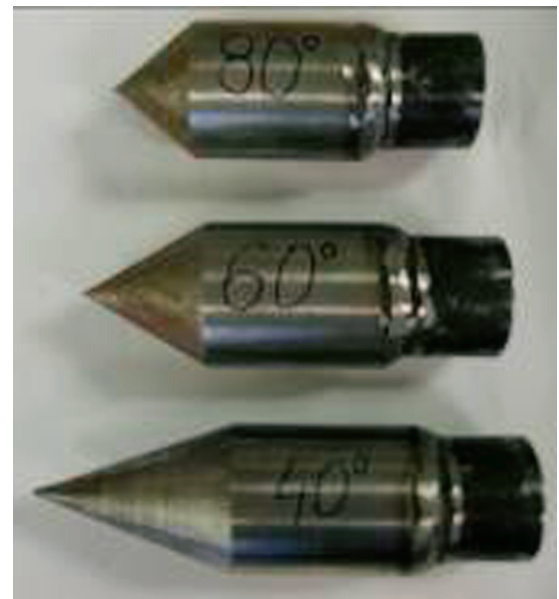

Figure 3 Cone specimens

Slika 3. Uzorci klina

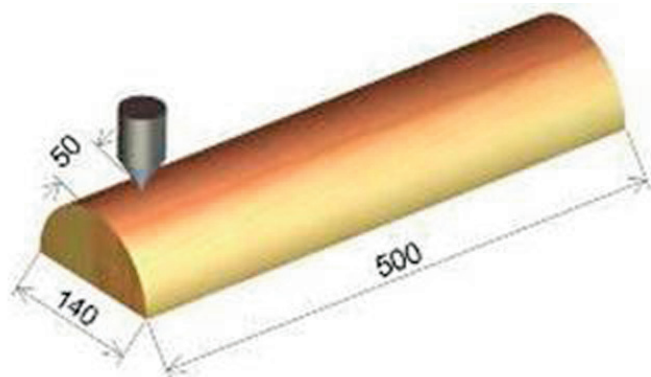

Figure 4 Geometrical parameters of a specimen Slika 4. Geometrijski parametri uzorka by software, which was connected with the universal strength testing machine Testometric M500-100CT with maximum operating force of $100 \mathrm{kN}$ (Figure 5). Working speed was set to $10 \mathrm{~mm} / \mathrm{min}$ and the measurement was carried out until the wood breakage. The specimen dimensions are shown in Figure 4.

The way how the cone penetrates the piece of wood (shown in Figure 6) and specimen stress behaviour are specific for elastic-plastic fracture mechanics.

\section{RESULTS AND DISCUSSIONS} 4. REZULTATI I RASPRAVA

The graph (Figure 7) shows the results of splitting force monitoring. Nine measurements were made for each cone and afterwards a representative force devel-

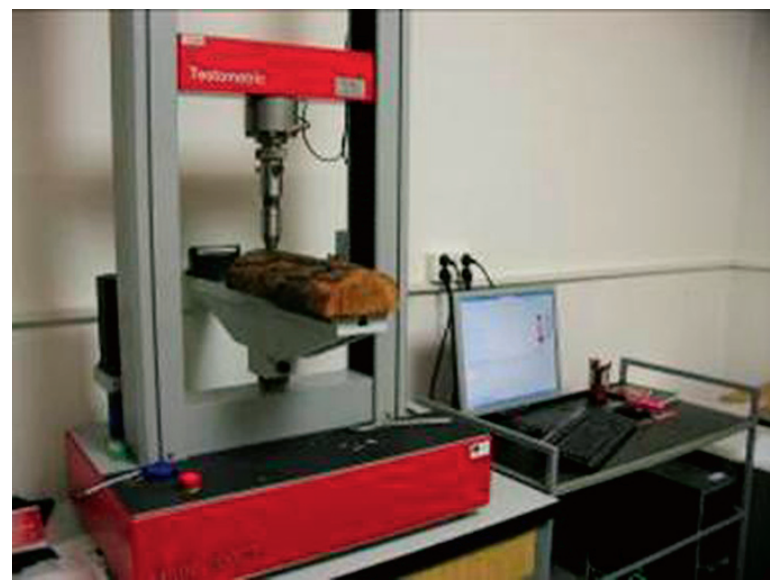

Figure 5 Cone testing Slika 5. Testiranje klina 


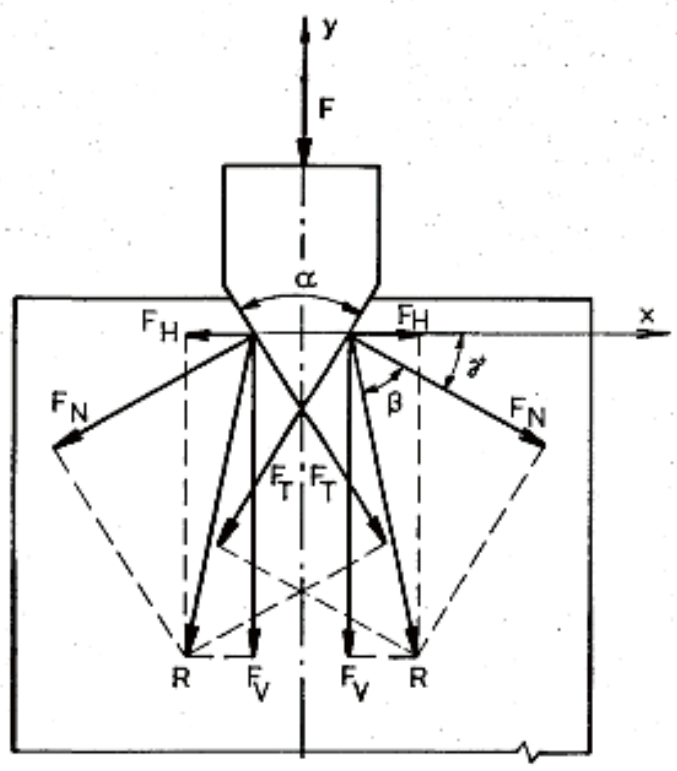

Figure 6 Resolution of forces caused by cone penetration $\left(F-\right.$ splitting force, $F_{\mathrm{H}}$ - horizontal force, $F_{\mathrm{V}}$ - vertical force, $F_{\mathrm{N}}$ - normal force, $F_{\mathrm{T}}$ - tangential force, $R$ - resultant force, $a$ - point angle)

Slika 6. Raspodjela sila pri prodoru klina $(F-$ sila cijepanja, $F_{\mathrm{H}}$ - horizontalna sila, $F_{\mathrm{V}}-$ vertikalna sila, $F_{\mathrm{N}}-$ okomita sila, $F_{\mathrm{T}}$ - tangencijalna sila, $R$ - rezultantna sila, $a$ - kut klina) opment was statistically chosen by median and plotted into the graph. The graph indicates that the optimal point angle is between 40 and 60 degrees. This fact has been confirmed by the calculated values of mechanical work, which represents the area below the splitting force curve. The calculation was performed in Microsoft Excel. The value for cone 1 (point angle of $40^{\circ}$ ) is represented by mechanical work of $151.3 \mathrm{~J}$. Value 124.6 $\mathrm{J}$ belongs to cone 2 (point angle of $60^{\circ}$ ). The third value $680.8 \mathrm{~J}$ was calculated for cone 3 (point angle $80^{\circ}$ ). This shows that the cone with point angle of $60^{\circ}$ (with the lowest splitting force) is the most suitable.

When splitting, it is necessary to exert a mechanical work that causes the plastic deformation. The created crack consequently helps to split the log, so it is necessary to design a broken pointed angle. At first, a smaller angle mitigates the penetration in a log and afterwards a bigger angle finishes the splitting. The cone shape was developed based on theoretical findings and obtained experimental values (Figure 8).

Finally, the cone was manufactured. Martensitic stainless steel (X39Cr13) was used as a workpiece material with dimensions $\varnothing 80 \times 200 \mathrm{~mm}$. At first, a clamping part with a $45 \mathrm{~mm}$ diameter and hole with a $24 \mathrm{~mm}$ diameter were machined at a lathe. Then, a roughing

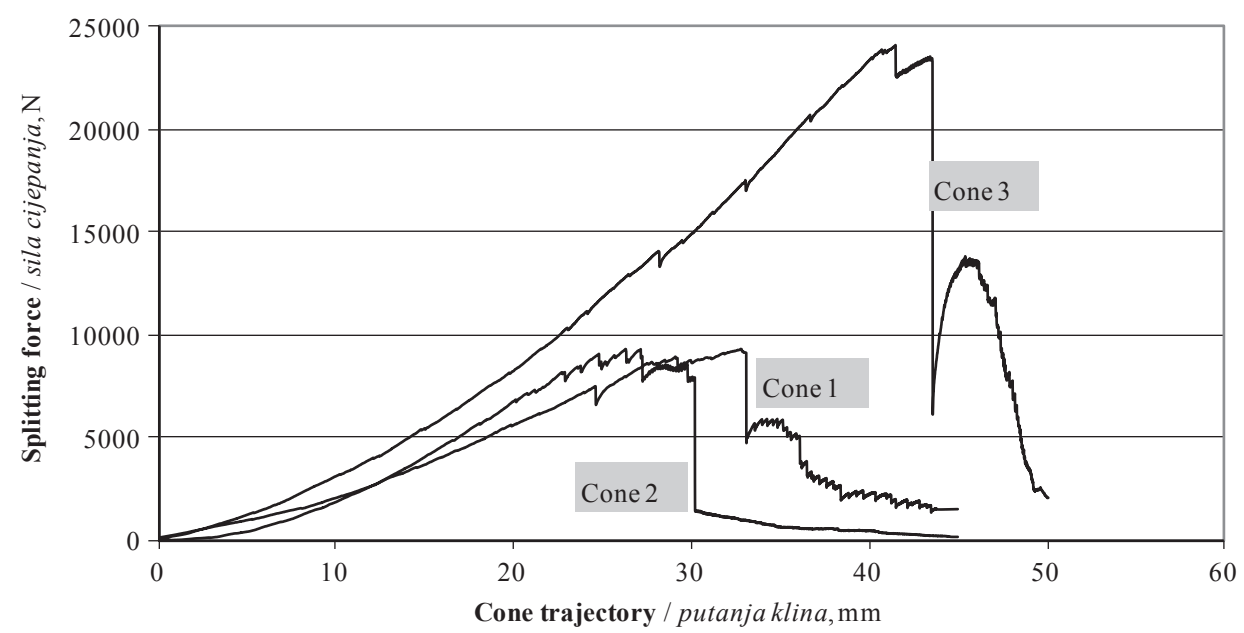

Figure 7 Splitting force process (cone 1 - point angle of $40^{\circ}$, cone 2 - point angle of $60^{\circ}$, cone 3 - point angle of $80^{\circ}$ ) Slika 7. Promjena sile cijepanja (klin 1 - kut klina $40^{\circ}$, klin 2 - kut klina $60^{\circ}$, klin 3 - kut klina $80^{\circ}$ )

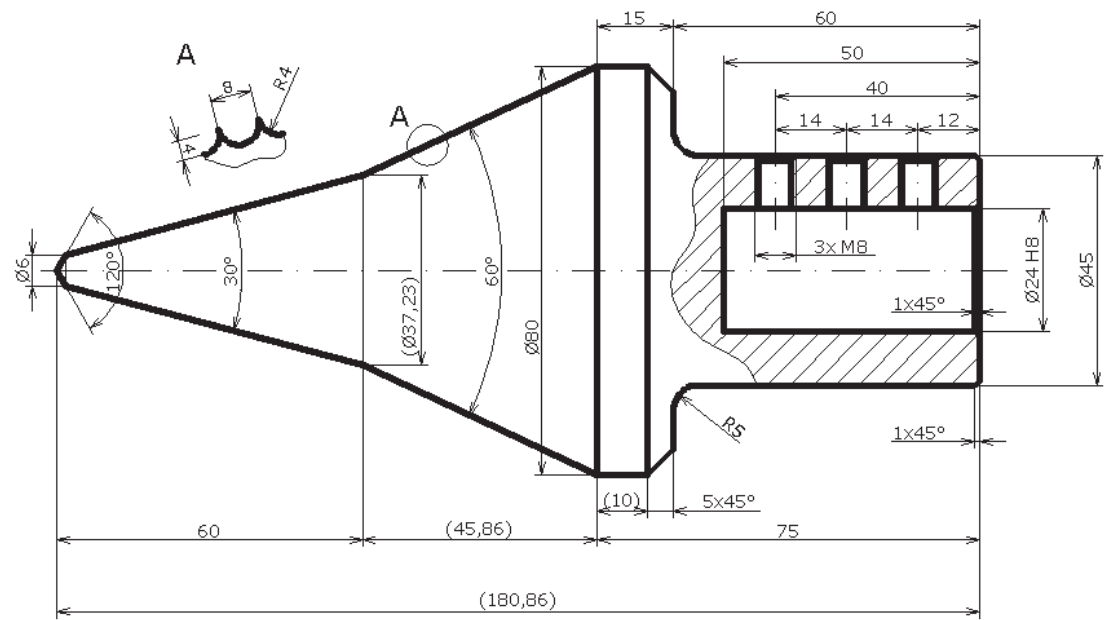

Figure 8 Design of the cone

Slika 8. Dizajn klina 


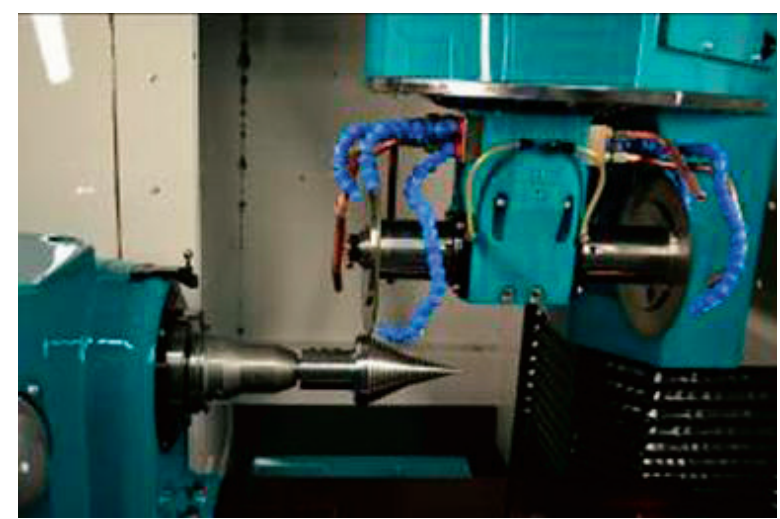

Figure 9 Manufacturing of cone

Slika 9. Proizvodnja klina

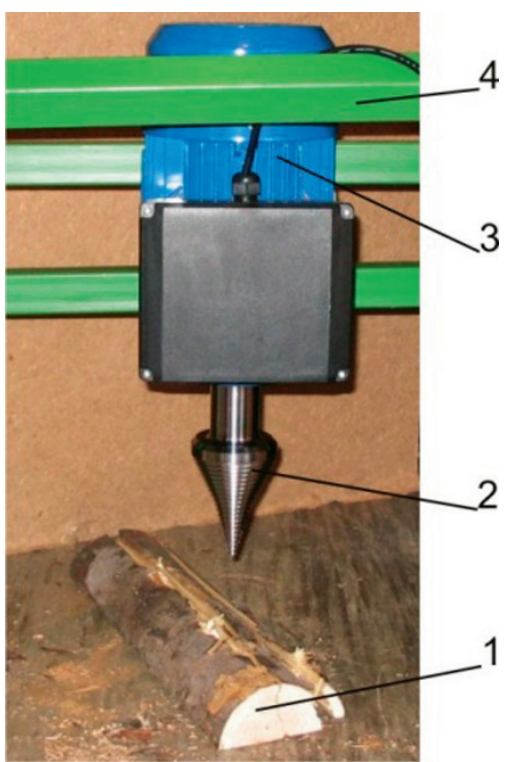

Figure 10 Experimental apparatus ( 1 - wood specimen, 2 - cone, 3 - electromotor / engine, 4 - frame)

Slika 10. Eksperimentalni uređaj (1 - uzorak drva, 2 - klin, 3 - elektromotor / pogon, 4 - okvir)

process was performed at a lathe with working allowance of $5 \mathrm{~mm}$ on the conical part. The three holes were drilled and threaded at a drilling machine for engine shaft connection. The screw teeth were produced by milling at a CNC machine tool. They were afterwards grinded (Figure 9).

The log splitter (experimental apparatus) has been developed to determine the validity of the cone and its teeth shape design (Fig. 10). The electromotor has a power of $1.5 \mathrm{~kW}$ and the maximum rotational speed is $1420 \mathrm{rev} / \mathrm{min}$. The movement of the splitting cone (connected with the electromotor) into the splitting process is provided by the frame.

The initial experiments indicate that the material selection and geometry design were determined correctly. Four initial power measurements have been made with beech (Fagus sylvatica) specimens by using MI 2492 POWER Q instrument and the values ranged between 110 and $160 \mathrm{~W}$. The maximum power of the electromotor is $1.5 \mathrm{~kW}$, so obviously the splitting power is only $11 \%$.

\section{CONCLUSION \\ 5. ZAKLJUČAK}

This contribution deals with the design and construction of a log splitter. A set of experiments have been carried out to get an appropriate shape of the splitting cone and its teeth. The cone with point angle of $60^{\circ}$ (with the lowest splitting force) was chosen as the most suitable. On the basis of experimental results, the designed cone has been manufactured. The initial experiments indicate that the material selection and geometry design were determined correctly.

For the total verification of the log splitter, it is necessary to gather a sufficient amount of measurement data, and this will be the aim of the next study.

\section{REFERENCES}

6. LITERATURA

1. Atkins, T., 2009: The Science and Engineering of Cutting: The Mechanics and Processes of Separating, Scratching and Puncturing Biomaterials, Metals and Non-metals. Elsevier, Butterworth Heinemann, 432p.

2. Griffith, A. A., 1921: The phenomena of rupture and flow in solids. Philosophical Transactions of the Royal Society A, 221:163-198. http://dx.doi.org/10.1098/rsta.1921.0006

3. Kretschmann, D. E., 2007: Wood. Kirk-Other encyclopedia of chemical technology. New York: John Wiley \& Sons, p. 1-59.

4. Mečiarová, J.; Minárik, M., 2012: Konstrukční návrh a výroba kuželového klínu pro štípaní dřeva, Strojírenská technologie, XVII $(1,2)$ : 68-75.

5. Smith, I.; Landis, E.; Gong, M., 2003: Fracture and fatigue in wood. West Sussex: John Wiley \& Sons.

6. Stanzl-Tschegg, S. E., 2006: Microstructure and fracture mechanical response of wood. Int J Fract, 139:495-508. http://dx.doi.org/10.1007/s10704-006-0052-0

7. Suchomel, J.; Belanová, K.; Štollmann, V., 2011: Analysis of Occupational Diseases Occurring in Forestry and Wood Processing Industry in Slovakia. Drvna industrija, $62(3): 219-228$

8. Tschegg, E. K., 1986: Equipment and appropriate specimen shape for tests to measure fracture values (in German), Patent AT-390328.

\section{Corresponding address:}

Ing. MARIÁN MINÁRIK, Ph. D.

Department of Mechanics and Mechanical Engineering Faculty of Environmental and Manufacturing Technology Technical University in Zvolen

Študentská 26 960 53, Zvolen, SLOVAKIA e-mail: minarik@tuzvo.sk 